\title{
Aboriginal groups seek representation on Pan-Canadian Public Health Network
}

Previously published at www.cmaj.ca

$\mathrm{F}$ ederal refusal to include Aboriginal groups in the PanCanadian Public Health Network - the country's main national public health advisory body - helped exacerbate pandemic (H1N1) 2009, health experts familiar with Aboriginal communities say.

"They are making uninformed decisions," says Assembly of First Nations Public Health Advisor Kim Barker, "and they don't even know it."

The exclusion of Aboriginal groups left the Public Health Agency of Canada (PHAC) playing catch-up in attempts to later include First Nations in Canada's Pandemic Influenza Plan, says Janet Smylie, an expert on federal aboriginal health policies with St. Michael's Center for Inner City Health and the University of Toronto in Ontario.

"It is very possible that if First Nations chiefs or their representatives had been directly at the Pan-Canadian Public Health Network table, at least some of the morbidity and mortality experienced in northern Manitoba by H1N1 could have been averted by more rapid mobilization of Tamiflu, and more rapid mobilization of resources and health workers to the affected communities."

Although the needs of First Nations were belatedly addressed in an appendix added to the pandemic plan after the virus hit First Nations communities, the plan still does not address the needs of Canada's 55000 Inuit people, whose suffer great vulnerability to pandemics and live with elevated rates of tuberculosis and meningitis.

Created by federal, provincial and territorial health ministers in 2005, the Pan-Canadian Public Health Network is designed to encourage different levels of government and experts to col-

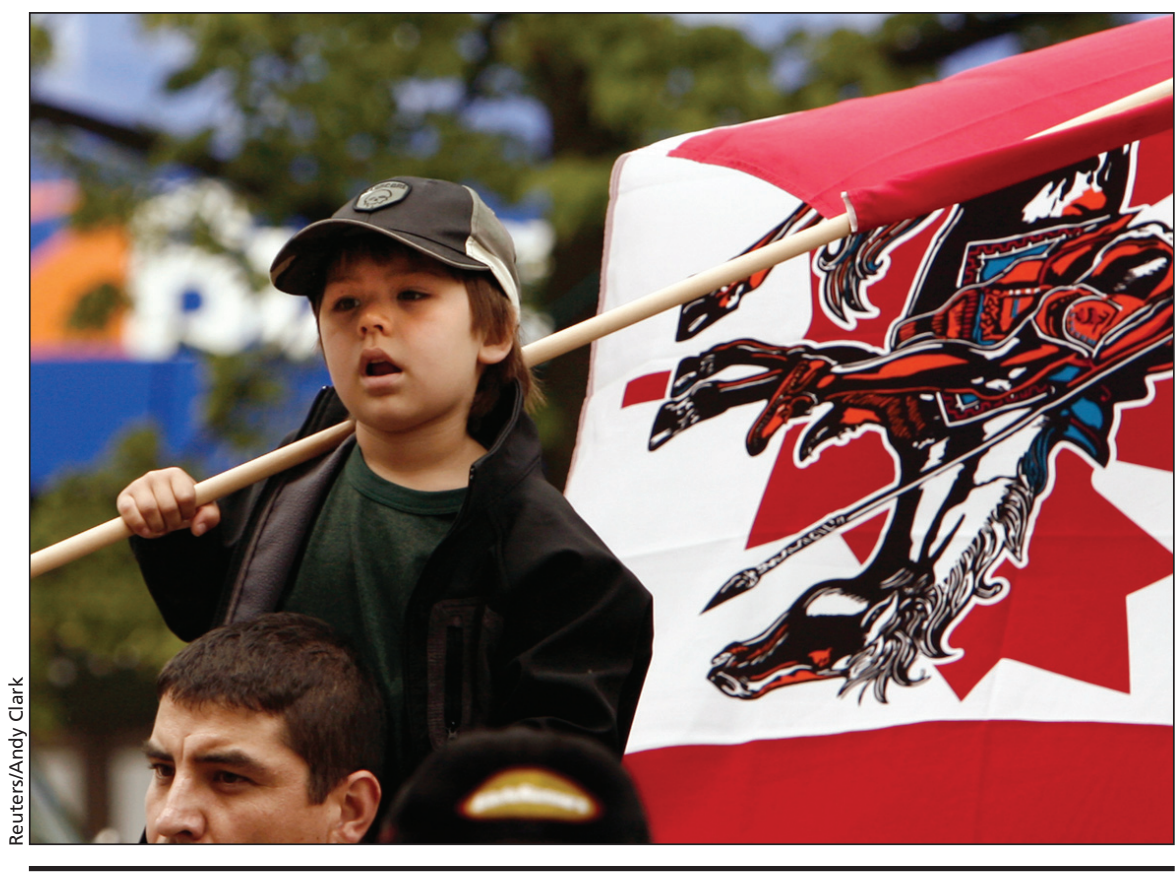

A young native boy takes part in a protest staged in Vancouver, BC, to bring attention to poverty, health and social problems facing Aboriginals living on and off reserves.

lectively tackle public health issues and emergencies. It is cochaired by Dr. David Butler-Jones, the country's chief public health officer, and Dr. Perry Kendall, the chief medical officer of British Columbia.

The network oversaw the development of a Canadian Pandemic Influenza Plan for the Health Sector, and a Pan-Canadian Pandemic Vaccine Strategy. "A key to the Network's effectiveness lies in its connectedness," PHAC managers state on the agency's website (www.phn -rsp.ca/About_e.html).

The network is composed of a 17member national council drawn from various governments and six expert groups in the areas of communicable disease control, emergency preparedness, laboratories, surveillance, chronic disease control and health promotion. Although its mission statement says it includes "academics, scientists, public servants and members of nongovernmental organizations," it has no official representation from any organization representing Canada's 1.3 million Aboriginal people and has often been criticized for favouring the participation of Health Canada bureaucrats.

Smylie notes that while there is at least one Aboriginal person on the council and one or two on a few of the expert groups, "Aboriginal governing, land claim and stakeholder organizations with the exception of the territory of Nunavut are not represented at all. All of the Aboriginal experts I could identify were working for federal or provincial or territorial governments."

Smylie adds that "the network's ability will be seriously hampered by the lack of inclusion of First Nations, Inuit, and Metis stakeholders. The network should not rely on [Health Canada officials] to liaise with Aboriginal people. To start with, they will miss the majority of Aboriginal people who 
live in cities, and they will miss all Metis - who make up one third of Canada's Aboriginal population."

Mary Simon, president of Inuit Tapiriit Kanatami, believes the Inuit voice is lost. "Inuit have been consistent in seeking high level representation at Parliamentary standing committees, and more recently in asking that an Inuit specific annex be included to the Canadian pandemic plan. Without someone on the network who understands these realities, we feel our issues will not get addressed."

Barker notes that both the Assembly of First Nations and Inuit Tapiriit Kantami first began pushing for representation when the notion of creating the network emerged in 2005. Four years later, Barker says Ottawa "is still sitting on the fence. The focus is on consultation with us, not on inclusion. And that's very dangerous."

Barker also believes the Assembly of First Nations has not been invited to join the network "because there seems to be an opinion the topics we bring are political."

Although Métis National Council Minister for Health David Chartrand declined to discuss the network, he recently accused Ottawa of failing to consult Métis leaders on pandemic (H1N1) 2009.

Health Canada, meanwhile, referred written questions about the network to PHAC, where a request for an interview with Butler-Jones was declined. In a written statement, PHAC spokesman Robert Paterson said "Health Canada and PHAC do not have a role in selecting the PHN membership."

It's up to the federal, provincial and territorial governments to select representatives, says Paterson, who defended the federal government's decision to select senior Health Canada officials to represent Aboriginal people.

Nova Scotia Deputy Minister of Health Promotion and Protection Duff Montgomerie, who serves as the network's provincial and territorial deputy minister liaison, also defends the network's approach to handling Aboriginal matters. "There's been incredible sensitivity on First Nations issues," he says, noting that political tensions invariably influence the operation of the network. "There is always a tension between the Government of Canada and the province and territories around how First Nations are treated."

Montgomerie insists such tensions are not an impediment. "At the public health network table, it's more about keeping Canadians safe. Like what's the most important discussion we can around our populations, whether it's the Inuit, or African Canadians, or First Nations."

But the inclusion of Aboriginal groups warrants examination, Montgomerie adds. "We as a network, all of us, and I include myself, should probably work harder to ensure that we're getting direct input."

Isaac Sobol, chief medical officer of health for Nunavut, and a member of the public health network's national council, would like representatives of First Nations, Metis, and Inuit communities to be included within its struc- tures. He'd also like a formal Aboriginal advisory body to be established.

Yet the situation doesn't appear entirely bleak. Sobol says that the federal government has at times been very responsive: "The federal government has been very supportive of Nunavut's need for epidemiology studies, both with $\mathrm{H} 1 \mathrm{~N} 1$, and on previous occasions, and has provided us with teams of epidemiologists on any occasion when we have requested their assistance."

Margo Greenwood, director of the National Collaborating Centre for Aboriginal Health, which is funded by PHAC, also thinks the time has come to formally include Aboriginal organizations on the network's council. "We need to have a voice, she says. "In facing emerging challenges, we have to have voices there. H1N1 is a really good example of why." — Paul Webster, Toronto, Ont.

DOI:10.1503/cmaj.109-3073

\section{Banning 'magic mint' could slow research}

Previously published at www.cmaj.ca

$S$ alvia divinorum can beam you to Mars. It can eradicate gravity. It can show you things that will make you howl with laughter and things that will make you scream in fear. But it only does these things in your head and only for about 15 minutes.

Millions of people have embarked on short-haul head trips after smoking Salvia divinorum, a plant from the mint family. Thousands have posted their hallucinogenic journeys on YouTube. In one video, viewed some two million times, a young woman says her mouth is falling off.

Some lawmakers believe Salvia divinorum, a.k.a. 'magic mint' or 'diviner's sage,' is dangerous. About a dozen countries have banned it, including Australia and Belgium. Selling it in parts of the United States will also earn you a fine and jail time. But it's legal in

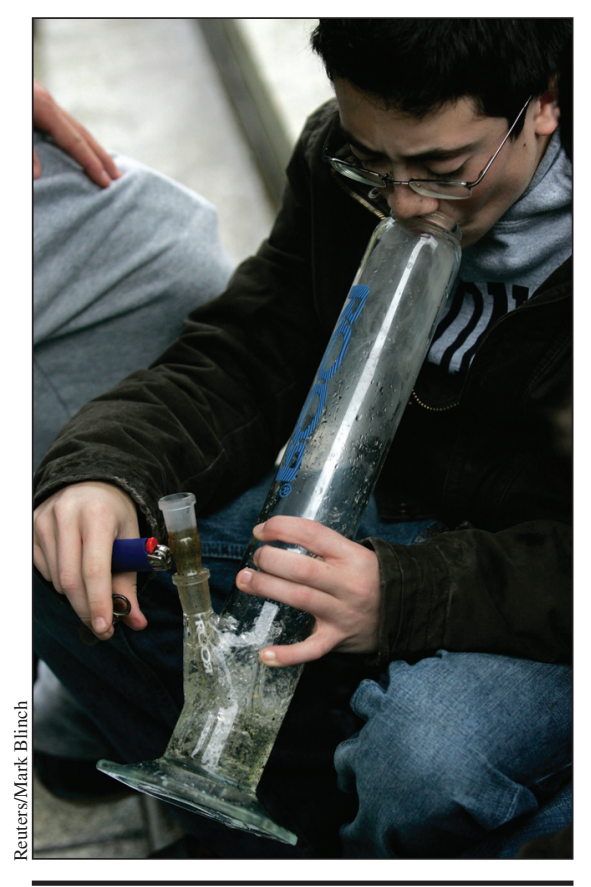

Salvia divinorum is smoked in a bong and induces short, vivid hallucinations. 